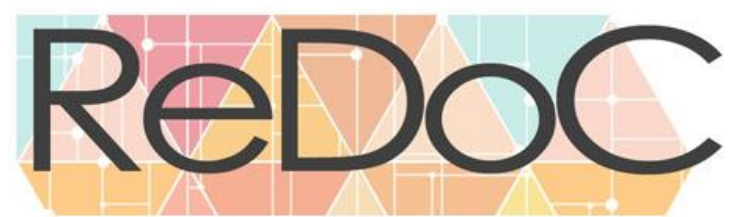

Revista Docência e Cibercultura

\title{
O CANDOMBLÉ SOB A MIRA DO RACISMO E DO TERRORISMO RELIGIOSOS: categorias e identidades reinventadas
}

\author{
CANDOMBLÉ UNDER THE SIGHT OF RACISM AND RELIGIOUS TERRORISM: categories and \\ identities reinvented
}
CANDOMBLÉ BAJO LA VISTA DEL RACISMO Y EL TERRORISMO RELIGIOSO: categorías e identidades reinventadas

Ozaias da Silva Rodrigues ${ }^{1}$

\section{RESUMO}

O tema desse trabalho é a discussão em torno dos ataques contra as religiões afro, com foco no Candomblé. A partir disso objetiva-se compreender as categorias que são usadas para definir esses ataques e outras questões relacionadas ao tema, como a questão identitária dos candomblecistas. O método consistiu em pesquisa de campo, pesquisa bibliográfica e entrevistas semi-estruturadas. Os resultados apontam que a identidade candomblecista foi reinventada nesse contexto de violação de direitos e que novas categorias estão sendo utilizadas para definir os ataques. Conclui-se então que a discussão em torno do tema deve ser feita a fim de acompanhar as mudanças nesse campo de pesquisa.

Palavras-chave: Racismo religioso. Terrorismo religioso. Intolerância religiosa. Candomblé.

\section{RESUMEN}

El tema de este trabajo es la discusión en torno a los ataques contra las religiones afro, con un enfoque en el Candomblé. A partir de esto, el objetivo es comprender las categorías que se utilizan para definir estos ataques y otras cuestiones relacionadas con la temática, como la cuestión de la identidad de los candomblistas. El método consistió en investigación bibliográfica y entrevistas semiestructuradas. Los resultados muestran que la identidad candomblecist se reinventó en este contexto de vulneración de derechos y que se están utilizando nuevas categorías para definir los ataques. Se concluye entonces que la discusión en torno al tema debe realizarse para seguir los cambios en este campo de investigación.

Palabras clave: Racismo religioso. Terrorismo religioso. Intolerancia religiosa. Candomblé.

Submetido em: 01/12/202 - Aceito em: 24/04/2021 - Publicado em: 12/07/2021

${ }^{1}$ Licenciado Pleno em História pela Universidade Federal do Ceará (UFC), Mestre em Antropologia pelo PPGA Associado entre a Universidade Federal do Ceará e a Universidade da Integração Internacional da Lusofonia Afro-brasileira (UFC/UNILAB) e doutorando em Antropologia Social pelo PPGAS da Universidade Federal do Amazonas (UFAM). Bolsista FAPEAM. 


\section{ABSTRACT}

The theme of this work is the discussion around attacks against afro religions, with a focus on Candomblé. From this, the objective is to understand the categories that are used to define these attacks and other issues related to the theme, such as the identity issue of Candomblecists. The method consisted of field research, bibliographic research and semi-structured interviews. The results show that the candomblecist identity was reinvented in this context of violation of rights and that new categories are being used to define the attacks. It is concluded then that the discussion around the theme must be made in order to follow the changes in this field of research.

Keywords: Religious racism. Religious terrorism. Religious intolerance. Candomblé.

\section{INTRODUÇÃO}

Neste artigo discuto as categorias usadas para definir os ataques às religiões afro - além dos ataques em si - a partir de uma pesquisa de campo que foi realizada em Fortaleza e região metropolitana, entre 2018 e 2020. Pelo menos treze entrevistas foram feitas e a partir da narrativa dos interlocutores, junto com uma bibliografia específica, serão discutidos os ataques às Religiões de Matrizes Africanas (RMAs) e outras questões correlatas. Tratarei primeiramente da questão dos ataques às RMAs, a partir de dois relatórios sobre casos de intolerância e violência religiosas e posteriormente discutirei as categorias racismo religioso e terrorismo religioso. Finalizo discutindo os processos identitários dentro do Candomblé que se relacionam com esse contexto de violência religiosa.

Em âmbito nacional há várias iniciativas de mapeamento de casos de intolerância/racismo religioso, mas aqui comentarei apenas duas que são as seguintes: de 2011 temos o Mapa da Intolerância Religiosa - Violação ao Direito de Culto no Brasil, de autoria de Marcio Alexandre Gualberto e temos o RIVIR - Relatório sobre Intolerância e Violência Religiosa no Brasil - Resultados preliminares, que foi publicado em 2016 e faz um balanço dos anos de 2011 a 2015.

A primeira iniciativa citada, o Mapa da Intolerância Religiosa - Violação ao Direito de Culto no Brasil usa esses dois conceitos já referidos e associa, inclusive, a intolerância religiosa ao racismo. A partir dos exemplos que são dados no Mapa percebe-se que: se podemos falar em racismo institucional é possível também falarmos em intolerância institucional, tendo em vista as formas discriminatórias e vexatórias com as quais as instituições públicas tratam dos casos de violação ao direito de culto no Brasil. Mesmo trazendo um amplo espectro de religiões presentes no território brasileiro o Mapa da Intolerância é correto em destacar as Religiões de Matrizes Africanas (RMAs) como aquelas que se destacam na paisagem religiosa do país 


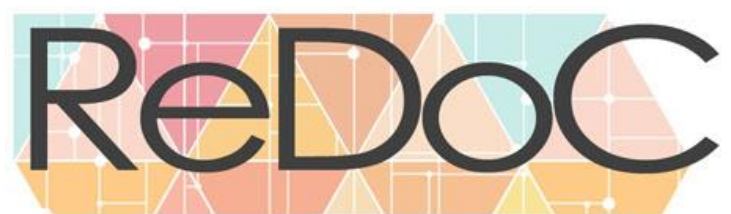

Revista Docência e Cibercultura

quando se fala em violência religiosa ou intolerância, como se pode ver na Apresentação e no Prefácio do mesmo.

Daniele Mozena, por exemplo, ao resenhar o Mapa da Intolerância escreve:

As religiões de matriz africana, como o Candomblé e a Umbanda, por exemplo, talvez sejam os maiores alvos de preconceito e intolerância religiosa no Brasil. São tradições religiosas que carregam o estigma do preconceito desde a época colonial, não necessariamente pela tradição religiosa em si, mas simplesmente por fazer parte da cultura negra. São inúmeros os casos agressivos em relação a essas tradições religiosas, demonizando-as e lhe atribuindo a origem dos sortilégios e possessões (MOZENA, 2011, p. 4).

Aqui critico dois pontos dessa citação: primeiro, devemos substituir o termo "talvez" da frase "talvez sejam os maiores alvos de preconceito e intolerância religiosa..." por "com certeza são", porque é isso que iniciativas como o Mapa da Intolerância, a literatura acadêmica e a narrativa dos interlocutores confirmam ${ }^{2}$. Em segundo lugar: no caso dos povos africanos não há como separar suas culturas de suas religiosidades, o que contraria o que Mozena afirmou de que a perseguição que as RMAs sofrem não é pela religiosidade em si, mas porque fazem parte da cultura negra. Como qualquer estudo antropológico sobre culturas deve deixar explícito é preciso dizer que a religião é um componente básico da cultura, de forma que não é possível, nesse caso, como sugeriu Ivanir dos Santos (2016), criar uma falsa separação entre ambas no caso afro-brasileiro ou africano. Penso então que a perseguição se dá exatamente porque essa religiosidade tem raízes negras, africanas, pois ambas estão vinculadas.

\footnotetext{
${ }^{2}$ Sobre isso aponto que: 1) O próprio Marcio Alexandre Gualberto afirma que no "Brasil, um capítulo especial da intolerância religiosa é dedicado às religiões de matrizes africanas. Os cultos afro-brasileiros foram perseguidos e criminalizados durante longo período da história brasileira e são, até hoje o alvo principal desta intolerância em nossa história recente" (GUALBERTO, 2011, pp. 12-13). Além disso, "Nos últimos anos o movimento ecumênico vem se enfraquecendo e, concomitantemente, o que se vê é um crescimento vertiginoso das igrejas neopentecostais e com ele um recrudescimento da intolerância religiosa, principalmente contra as religiões de matrizes africanas, notadamente o candomblé" (GUALBERTO, 2011, p. 14). Por fim, “[...] Nessa "guerra” da fé, os seguidores de religiões afro-brasileiras são as vítimas mais frequentes" (GUALBERTO, 2011, p. 26). "Historicamente, as religiões de matriz africana, sofreram toda sorte de discriminação e perseguição, inclusive policial" (GUALBERTO, 2011, p. 107).

2) Também há no RIVIR (2011-2015) uma referência a isso: "Um último conjunto de dados sobre as matérias da imprensa escrita tratam do perfil das vítimas e dos agressores. Há predominância de fiéis de religiões de Matriz Africana entre as vítimas e uma maioria de agressores não identificados, com predominância de evangélicos entre os identificados" (2016, p. 52). Nesse mesmo Relatório (p. 55) os gráficos apontam que 53\% das vítimas de violência religiosa são de RMAs (maioria), e os que mais agridem são evangélicos num total de $27 \%$.

3) Uma matéria do O Globo, de 2019, aponta isso também: https://oglobo.globo.com/sociedade/denuncias-deataques-religioes-de-matriz-africana-sobem-47-no-pais-23400711. Acesso em: 13/09/2020.
} 


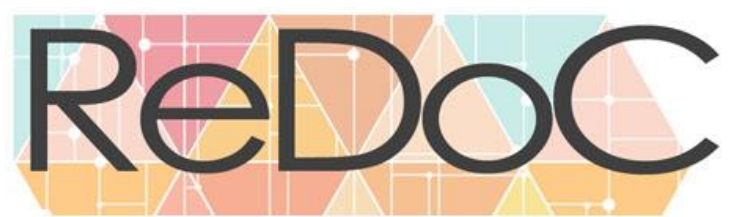

Revista Docência e Cibercultura

Gualberto (2011) sugere como a lógica monoteísta radical alimenta a intolerância/racismo religioso, pois essa visão de uma verdade única e absoluta "já implica numa concepção preconceituosa e racista na qual as religiões afro-brasileiras são taxadas de feitiçaria, bruxaria, macumba e outros termos depreciativos" (p. 15). No Mapa os exemplos de intolerância/racismo religioso que Gualberto traz são relacionados ao abate religioso, aos ataques da Igreja Universal do Reino de Deus (IURD) através de publicações que demonizam as entidades cultuadas e ao emblemático caso de mãe Gilda que teve sua foto usada num jornal da IURD de forma indevida e outros. $\mathrm{O}$ autor usa o conceito de intolerância religiosa para se referir a esses exemplos, mas em outros casos há menções à discriminação racial e à identidade racial das vítimas, tornando o racismo religioso um fenômeno contíguo à intolerância religiosa.

A outra iniciativa citada, o Relatório sobre Intolerância e Violência Religiosa no Brasil (RIVIR), começa por fazer várias afirmações amparadas em leis que garantem a liberdade de culto e de fé no país. Logo em seguida há uma narrativa histórica que explica como a intolerância se manifestou ao longo do tempo no país. É mostrado como a igreja católica colonial, a partir de um ponto de visto etnocêntrico, demonizava qualquer prática religiosa que não fosse a católica, sendo os povos indígenas as primeiras vítimas dessa intolerância católica. Depois são citados os protestantes, os judeus, os espíritas e os povos africanos escravizados (muçulmanos, chamados de Malês, ou praticantes de cultos tradicionais/ancestrais): todos estes vítimas do poderio católico.

Os pesquisadores enfatizam que o tema ainda é incipiente no meio jornalístico escrito (impresso, em sites/portais e revistas) e que é abordado de forma inadequada, além dos casos locais não terem tanta repercussão como outros casos que ganham "ares nacionais". Mas partindo exatamente para o que nos interessa o referido relatório, num determinado tópico, traz notícias de intolerância e violência religiosa relacionadas ao racismo. Nesse tópico percebe-se que o racismo é a base estruturante de diversas violações no país, entre elas a violação do direito ao culto.

Ao falar do despreparo dos órgãos públicos em lidarem com a questão o(a)s autore(a)s do RIVIR colocam que:

Diante disso, os movimentos sociais que lidam com a questão religiosa, principalmente os que envolvem religiões de matrizes africanas, [têm] uma discussão para se utilizar o termo "racismo religioso" de modo a conseguirem efetivar suas denúncias de modo eficaz quando recorrem à polícia e órgãos de justiça brasileira (RIVIR, 2016, p. 96).

Assim, ao acionarem a categoria racismo as vítimas esperam ter suas demandas atendidas e melhor compreendidas pelas autoridades e como é colocado no Relatório a tipificação religiosa do racismo é possível através da chamada Lei Caó. No caso das RMAs o conceito de racismo 


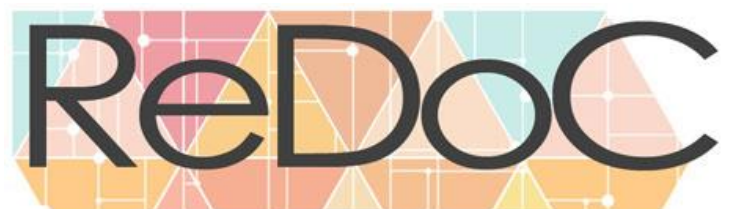

Revista Docência e Cibercultura

religioso é usado a partir da expectativa de que ele alcance mais consenso entre as autoridades do que o conceito de intolerância religiosa - dependendo de cada caso, claro.

Quando trazemos os dados do RIVIR a partir de informações da imprensa escrita (2019, p. 53) e olhamos para o perfil das vítimas dessas violências religiosas a partir do recorte 'COR' temos as seguintes porcentagens, em ordem crescente: indígenas, $0,2 \%$, brancos, $4,8 \%$, pardos, $5 \%$, pretos, $7,8 \%$. E quando olhamos para o perfil racial dos agressores temos, em ordem descrente: $4,7 \%$ de brancos, $0,5 \%$ de pardos, $0,3 \%$ de pretos $^{3}$. Logo, por mais que a população branca candomblecista seja também vítima do racismo religioso, as mais afetadas pelo mesmo são os pretos e pardos. Isso se configura como uma especificidade do racismo religioso que tem os seus principais alvos bem definidos. Por outro lado, temos que indivíduos brancos são os que mais agridem e dessa forma podemos ver, a partir desses dados, o quanto o modelo brasileiro de relações raciais se reproduz nesses conflitos de ordem religiosa.

No caso dos processos judiciais selecionados no RIVIR, no tocante às vítimas, os adeptos de RMAs aparecem em terceiro lugar com $7 \%$ de casos, ficando os adventistas, em primeiro lugar, com $45 \%$ e os evangélicos com $11 \%$, em segundo lugar. De forma geral, os dados da imprensa escrita e das ouvidorias divergem dos dados dos processos jurídicos, pois a partir de fontes diferentes temos dados diferentes. Entretanto, no geral, os dados indicam tendências já consagradas no âmbito das pesquisas sobre o assunto como indicam os dados da imprensa e das ouvidorias.

\section{A REALIDADE DAS RMAS: ENTRE O RACISMO, O TERRORISMO RELIGIOSO E AS SURPRESAS DO COTIDIANO}

Para aprofundar as questões apresentadas trago um relato de uma experiência que tive em um evento acadêmico que ocorreu no dia 12 de dezembro de 2019, em Salvador. No referido dia foi realizada uma mesa redonda que integrou a programação da VI REA - Reunião Equatorial de Antropologia. O tema debatido nessa mesa redonda teve como mote o racismo religioso no

\footnotetext{
3 As informações analisadas a partir das Ouvidorias mostram que no caso das vítimas temos, em ordem decrescente, $47 \%$ de pardos, $34 \%$ de brancos, $17 \%$ de pretos e $2 \%$ de indígenas. Ainda a partir do dados das Ouvidorias, mas no caso dos agressores temos, em ordem decrescente, 53\% de brancos, 34\% de pardos, $12 \%$ de pretos e $1 \%$ de indígenas. Essas informações das Ouvidorias, que trazem porcentagens distintas e significativas quando comparadas às informações extraídas da imprensa, mostram nuances distintas do fenômeno da violência religiosa (pp. 68-71), seja do lado das vítimas ou dos agressores. O importante aqui é perceber que os dados não se anulam ou se contestam mutuamente, mas mostram realidades distintas a partir de fontes diferentes.
} 


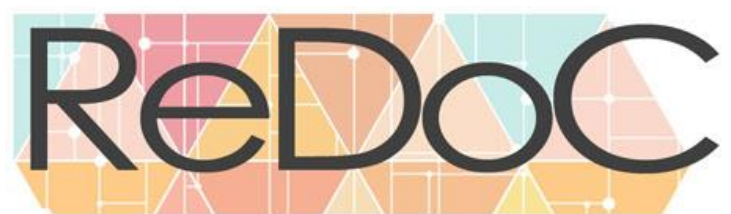

Revista Docência e Cibercultura

Brasil. Estavam compondo a mesa o professor Ordep Serra Trindade, docente da UFBA, o professor Marcelo Camurça, docente aposentado da UFJF, a ialorixá Nívia, de Salvador, o babalorixá Leonel Monteiro, da Associação Brasileira de Preservação da Cultura Afroameríndia e o ogã e advogado Cleifson Dias Pereira ${ }^{5}$.

Resumirei o que os palestrantes falaram durante a mesa redonda. O professor Ordep, do pouco que acompanhei de sua fala, falou na mentalidade escravista que atravessa a nossa sociedade. Já a ialorixá Nívia falou em terrorismo religioso a partir de casos em que pais e mães de santo foram expulsos do próprio terreiro ou foram obrigados a quebrarem os objetos de culto sob a coerção de criminosos. Lembro das palavras contundentes que ela proferiu, pois as palavras dela tinham um peso único: o peso de quem já sofreu com aquilo que ela estava chamando de terrorismo religioso.

Pai Leonel falou em obscurantismo religioso e citou um caso chocante de racismo religioso que ocorreu em Salvador do qual ficou sabendo e compartilhou com os presentes. O professor Marcelo Camurça falou sobre o Comitê Laicidade e Democracia, recentemente criado dentro da ABA - Associação Brasileira de Antropologia, de seus objetivos e se colocou à disposição para receber demandas e propostas para o Comitê, enquanto integrante do mesmo. O ogã Cleifson reafirmou a identidade negra no Candomblé, falou em desobediência epistêmica e no farto arcabouço jurídico que trata da questão da intolerância e do racismo e ainda citou o Centro de Referência de Combate ao Racismo e à Intolerância Religiosa Nelson Mandela, localizado em Salvador.

A partir desse evento e da fala de mãe Nívia comecei a pesquisar sobre o conceito de terrorismo religioso e encontrei referências, diretas e indiretas, a ele em algumas matérias de sites de jornais, em bibliografia acadêmica e na fala de alguns interlocutores da pesquisa de campo. As

\footnotetext{
${ }^{4}$ Ogã - cargo masculino: responsável pela matança dos animais para sacralização dos mesmos, pelos atabaques e pela música ritual que coordena o culto aos orixás. Não entra em transe e podem exercer função administrativa no terreiro também.

${ }^{5}$ Essa mesa foi mediada pela professora Fátima Tavares, da UFBA.
} 


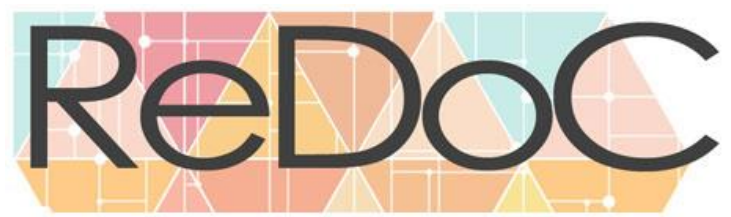

Revista Docência e Cibercultura

m,atérias consultadas acerca disso são de $2008^{6}, 2013^{7}, 2017^{8}, 2019^{9}$ e $2020^{10}$ e a partir da leitura dessas matérias sugiro que os anos de 2017, 2018 e 2019 foram os anos mais violentos no sentido quantitativo.

Inicialmente é preciso apontar uma definição desse termo. Em 2019, num contexto onde ataques de traficantes a terreiros do Estado do Rio de Janeiro têm se tornado lugar comum ${ }^{11}$, a jornalista Flávia Oliveira escreveu uma matéria no O Globo intitulada Ataque a terreiros é terrorismo ${ }^{12}$. Logo de início ela escreve:

Foi o historiador Luiz Antonio Simas que, após a destruição do terreiro de candomblé no Parque Paulista, em Duque de Caxias, no início do mês, cobrou numa rede social outra denominação para os ataques aos cultos de matriz africana. No lugar de intolerância, terrorismo religioso. A frequência e a intensidade dos episódios, que misturam intimidação, ameaça, dano ao patrimônio, destruição de elementos sagrados, agressão física e até tentativa de homicídio, justificariam a ênfase. Neste ano, que mal passou da metade, a Comissão Contra Intolerância Religiosa já recebeu 200 denúncias de algum tipo de violência, mais que o dobro do total (92) de 2018 (OLIVEIRA, 2019).

Além disso,

O procurador Jaime Mitropoulos [...] já usou o conceito de terrorismo para classificar a escalada de violência contra terreiros por grupos armados da Baixada Fluminense, em particular. "Criminosos usam a religião como pretexto para intimidar, amedrontar e ameaçar a integralidade física e a vida das pessoas. Há viabilidade de enquadrar como terrorismo, se o tipo penal for enquadrado adequadamente (OLIVEIRA, 2019).

Assim, a partir dessas citações é possível usar o conceito de terrorismo religioso para definir, do ponto de vista da violação de direitos, um recrudescimento extremo da violência contra os terreiros e também, do ponto de vista penal, o enquadramento dessa violência enquanto

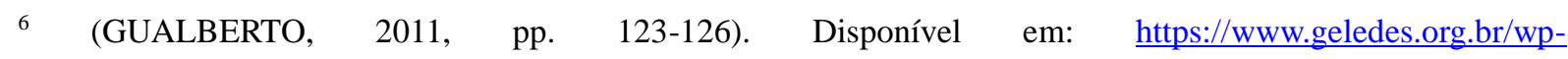
content/uploads/2014/06/Mapa_da_intolerancia_religiosa.pdf. Acesso em: 13/09/2020.

7 Disponível em: https://oglobo.globo.com/rio/traficantes-proibem-candomble-ate-roupa-branca-em-favelas9892892. Acesso em: 13/09/2020.

${ }^{8}$ Disponível em: https://veja.abril.com.br/brasil/em-nome-de-jesus-bandidos-destroem-terreiro-no-rio/. Acesso em: 13/09/2020. https://theintercept.com/2017/09/20/ataques-a-religioes-de-matriz-africana-fazem-parte-danova-dinamica-do-trafico-no-rio/. Acesso em: 13/09/2020.

9 Disponível em: https://www1.folha.uol.com.br/cotidiano/2019/08/policia-prende-8-traficantes-do-bonde-dejesus-que-atacava-terreiros-no-rio.shtml. Acesso em: 13/09/2020.

https://oglobo.globo.com/rio/mais-de-200-terreiros-estao-ameacados-no-estado-diz-pai-de-santo-23937214.

Acesso em: 13/09/2020.

${ }^{10}$ Disponível em: https://tab.uol.com.br/edicao/nacao-de-jesus/\#page10. Acesso em: 13/09/2020.

${ }^{11}$ Entre outras coisas, nas matérias consultadas era recorrente que os presídios aparecessem como os locais onde ocorrem a conversão evangélica de traficantes.

12 Disponível em: https://oglobo.globo.com/opiniao/ataque-terreiros-terrorismo-23818118. Acesso em: $30 / 11 / 2020$. 


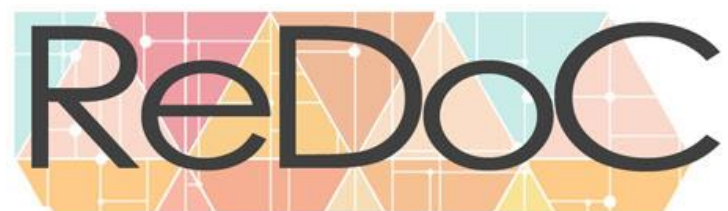

Revista Docência e Cibercultura

terrorismo ${ }^{13}$ na legislação. Oliveira (2019) também fala no discurso demonizante dos púlpitos neopentecostais que desemboca, de várias formas, na ação brutal de criminosos contra os terreiros, e além disso a autora defende que a violência contra os terreiros da Baixada Fluminense é terror e deve ser tratada como tal.

A partir da matéria anteriormente citada localizei uma matéria publicada em 10/09/2019 ${ }^{14}$ que estimulou Luiz Antonio Simas a reagir no seu Twitter ${ }^{15}$ sobre a violência contra os terreiros. O título da matéria é Líderes religiosos de Campos relatam ataques e ameaças de traficantes a terreiros. A partir dessa matéria destaco duas coisas: 1) 'clima de medo', 'ofensas virtuais', 'ameaças de morte', 'intimidação', 'restrição das atividades' e 'assassinatos' são as palavras que aparecem na matéria e resumem a realidade de Campo dos Goytacazes à época. 2) É importante dizer que essa violência também tem o sentido de marcar território, de controlar tudo o que acontece dentro das regiões dominadas por fracções criminosas, logo, o terrorismo religioso que se abate sobre os terreiros se vincula diretamente a disputa e controle territoriais ${ }^{16}$.

Uma matéria do $\mathrm{O}_{\text {Globo }}{ }^{17}$ trata de um evento proposto pelo Ministério Público Estadual do Rio de Janeiro, em 2019, para tratar sobre a intolerância religiosa e cita o babalawô Ivanir dos Santos que fala em terrorismo, associando-o diretamente ao narcotráfico. Os chamados 'Bondes' ou 'Gangues de Jesus' são citados na matéria e o procurador Jaime Mitropoulos fala em racismo, ódio e terrorismo religiosos. Essa reunião proposta pelo MPRJ representa a tentativa das autoridades em dar cabo dos inúmeros casos que envolvem o poder do narcotráfico e o terrorismo religioso, ou o que alguns chamam de narcopentecostalismo.

Das matérias de sites consultadas infere-se que essa intolerância/terrorismo religioso inclui o uso de armas de fogo e barras de ferro para obrigar mães/pais de santo a destruírem seus próprios terreiros, a expulsão de adeptos dos seus terreiros e residências, que se localizam em áreas dominadas por facções criminosas, e também homicídios. Afora isso há a proibição de uso de roupas de santo, adereços correlatos, som de atabaques e despachos nas ruas desses territórios.

\footnotetext{
${ }^{13}$ Lei $\mathrm{n}^{\circ}$ 13.260/2016, conhecida como Lei Antiterrorismo ou do Terrorismo.

${ }^{14}$ Disponível em: https://extra.globo.com/casos-de-policia/lideres-religiosos-de-campos-relatam-ataquesameacas-de-traficantes-terreiros-23938758.html?versao=amp\& twitter impression=true. Acesso em: 30/11/2020.

${ }^{15}$ Disponível em: https://twitter.com/simas luiz/status/1171762275126075395. Acesso em: 30/11/2020.

${ }^{16}$ Entre outras coisas Christina Vital da Cunha (2014) trata dessa questão do controle territorial no artigo Religião e criminalidade: traficantes e evangélicos entre os anos 1980 e 2000 nas favelas cariocas.

17 Disponível em: https://oglobo.globo.com/rio/mais-de-200-terreiros-estao-ameacados-no-estado-diz-pai-desanto-23937214. Acesso em: 13/09/2020.
} 
Em algumas matérias consultadas esses atos de terrorismo religioso, frequentemente, eram perpetrados contra mães de santo, contra mulheres de axé, mas há casos que são contra pais de santo. De uma forma ou de outra, o gênero das vítimas deve ser ressaltado aqui, pois é importante treinar o olhar para entender como o gênero se relaciona a esses atos de terrorismo religioso, até porque, quando olhamos os dados do RIVIR (2016, pp. 53-54), por exemplo, as maiores vítimas dessas violências são do gênero feminino num total $28,1 \%$, e 17, $5 \%$ são do gênero masculino. Já do lado dos agressores acontece o inverso: $29,1 \%$ são homens e 9,8\% são mulheres.

Numa matéria da Folha de São Paulo, de 2019, aparece o termo terrorismo religioso para definir esses atos, mas também aparece o termo intolerância religiosa. Na prática do terrorismo religioso há traficantes que ordenam esses atos de violência, sendo que, nessa e em outras reportagens, fica sugerido que o discurso demonizante proferido dos púlpitos das igrejas é o que alimenta esse terrorismo religioso. A "pregação" do púlpito é a teoria que fundamenta a prática terrorista desses traficantes que se dizem evangélicos. É basicamente isso que algumas matérias consultadas sugerem: a perseguição de traficantes aos terreiros passou a ocorrer após a conversão destes ao meio evangélico, logo, as lideranças evangélicas que estimulam esses ataques, usando sua autoridade espiritual, tem a sua grande parcela de culpa nesse terrorismo religioso, visto que esses ataques não são por acaso.

Uma contribuição dessa discussão temos em José Nery Moraes (2016) que escreve a partir do contexto amapaense e fala sobre o terrorismo religioso. Nas palavras dele os racistas religiosos, enquanto praticantes de uma fé distorcida e capazes das piores atrocidades, cometem o terrorismo religioso:

[...] com invasão e depredação das comunidades de Terreiro e igrejas católicas pelos traficantes de Cristo (narconazievangelistas), agredindo o patrimônio cultural e histórico, a fé ancestral e o valor ambiental afro-ameríndio, praticado quando há distorção da fé, o abuso do direito da liberdade de crença, de expressão e sua associação com o crime organizado, violando os direitos civis, constitucionais, coletivos, difusos, religiosos e os direitos humanos das vítimas, com a desqualificação do valor ambiental das comunidades de base ancestral (NERY, 2016, p. 17).

Assim, racismo religioso e terrorismo religioso são basicamente faces da mesma moeda e atingem os mesmos alvos: as comunidades de terreiro e os adeptos. Por mais que o exemplo tomado inicialmente seja o do Estado do Rio de Janeiro a prática do terrorismo religioso é uma realidade de outros contextos urbanos, como em Fortaleza, por exemplo. Podemos ver isso a partir dos relatos de um dos interlocutores ${ }^{18}$ da pesquisa de campo, o ogã Leno Farias. Ele não

${ }^{18} \mathrm{O}$ ogã Leno Farias é bem conhecido no contexto cearense entre os adeptos de RMAs e seus simpatizantes por sua defesa em prol dos povos de terreiro. Atualmente é presidente do Conselho Estadual de Promoção da Igualdade Racial. 


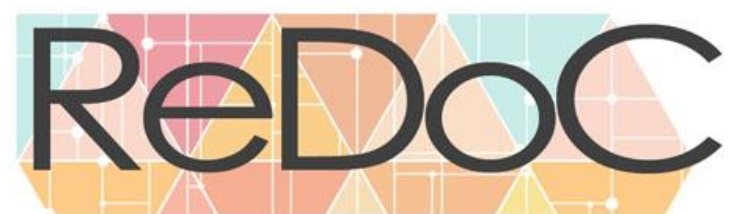

Revista Docência e Cibercultura

usa o termo terrorismo religioso, mas a sua fala sobre os traficantes que ameaçam os terreiros de variadas formas indica essa prática:

[...] No terreiro da mamãe, mesmo sendo mestra da cultura, um dia desses o tráfico foi lá e disse: "Minha vó, hoje a senhora não pode tocar não". É difícil encontrar algum terreiro que não tenha passado por algum problema.

[...] Teve problema de escola, a grande maioria é questão de vizinhança porque as igrejas se instalam, essas igrejas neopentecostais se instalam exatamente onde tem um terreiro. O terreiro tá aqui, pode prestar atenção, tem uma, duas, três perto. Por quê? Porque é estratégia. Não é à toa e alguns vilipêndios de direitos acontecem por conta do tráfico.

[...] O pessoal se incomoda com tambor, com o cantar, com as roupas. Por exemplo, lá no São Cristovão, há uns meses atrás, tava tendo um problema. A menina foi iniciada no Candomblé, tava andando com as roupas dela e o pessoal da boca disse assim: "Oh, aqui não pode não". E ela teve que ir lá no dono da boca e dizer assim: "Oh, cara, eu não tô fazendo nada, é a minha religião, e tal e tal...". Teve que negociar com o tráfico para poder ficar usando suas coisas no seu bairro (Diálogo realizado em 11/07/2019).

E falando dos evangélicos ele continua:

[...] Eles constituem uma base política, partidária, vários partidos políticos, voltados e ligados às igrejas e aí montam a tal da bancada evangélica, com prefeitura, governos de Estado, têm ligações escusas, infelizmente, com milícia, com tráfico e vão aos presídios. Cooptam lideranças de facções criminosas dentro dos presídios, transformam eles em crentes desviados, mas são crentes e começam a acionar e expulsar os terreiros. Que é o que nós estamos vendo agora com mais força. [...] Aqui teve uns terreiros na Praia do Futuro, naqueles morros da Praia do Futuro, que foram expulsos pelo tráfico. No Bom Jardim, no ano passado teve um caso em que o traficante entrou lá em "nome de Jesus" e escalonou todo mundo com tiros dentro do terreiro, que o cara que tava tocando tambor morreu e a mãe de santo também morreu, no IJF - Instituto Doutor José Frota. Existem casos assim em que eles mandam a gente parar de tocar. Então, não tá sendo fácil. Não tá sendo simples, mas não tem registro (Diálogo realizado em 11/07/2019).

Assim, além de ter que pedir permissão aos traficantes para exercerem sua religiosidade, os adeptos de RMAs também estão sujeitos a invasões violentas de seus locais de culto ${ }^{19}$, restrição de atividades e de uso de símbolos e até homicídio. De forma geral, essa violência vincula-se à influência evangélica como aponta o ogã Leno.

\footnotetext{
${ }^{19}$ A cantora Fabiana Cozza, em entrevista, falou em terrorismo religioso: "Acho que a minha resposta enquanto artista e cidadã deveria vir de forma poética, mas muito conectada com aquilo que é importante para mim, que é esse lugar que tanto me abraça e que tem sofrido ataques severos há muitos anos", disse, referindo-se aos ataques contra as religiões de matriz africana. "O que está acontecendo é um terrorismo religioso. O que é quebrar um terreiro? Expulsar mãe de santo ou pai de santo de suas casas?...". Disponível em: https://www.acidadeon.com/NOT,0,0,1550927,Passei-a-conhecer-muito-de-mim-depois-que-comecei-a-cantardiz-Fabiana-Cozza.aspx. Acesso em: 21/04/2021.
} 
Essa intersecção entre crime e religião (pentecostalismo) foi discutida, entre outros pesquisadore(a)s ${ }^{20}$, por Christina Vital da Cunha (2014) que ao discutir esses dois universos, teoricamente distintos e antagônicos, ressalta a convivência entre ambos, evidenciado assim uma relativa imbricação de fronteiras supostamente instransponíveis. Como ela mesmo escreve, ao contar sobre uma experiência no morro Santa Marta, "uma gama de referências bibliográficas sugeria a existência de uma distinção identitária e gramatical entre bandidos e evangélicos" (CUNHA, 2014, p. 64). Cito Cunha (2014) para falar exatamente sobre essa intersecção entre crime e religião, pois a autora não utiliza o conceito de terrorismo religioso. Essa associação entre um neopentecostalismo exacerbado e traficantes que expulsam, ameaçam e até matam afrorreligiosos, "em nome de Deus", é basicamente o que define o referido conceito.

Cunha (2014) aponta o quanto que a ruptura entre o universo do crime organizado e da religião não existe mais e explicita o quanto o fenômeno dos traficantes evangélicos representa uma ruptura com a ideia de ruptura entre esses nichos ${ }^{21}$. Indo além nessa questão lembro do filme Cidade de Deus em que o personagem Zé Pequeno tinha ligação com alguma entidade ou orixá. Zé Pequeno era traficante e a sua ligação com o sobrenatural afrorreligioso aparece em uma cena do filme, mas fica explícita a partir da guia/fio de conta que ele sempre carregava no pescoço e que tem as cores de Exu. Assim, o que a junção entre crime e religião aponta é que os criminosos, assim como os que vivem sob a lei, também têm a necessidade de se conectarem ao sobrenatural, seja ele qual for. A diferença, nesse caso, está na vinculação religiosa, pois uma delas é a que demoniza e a outra é a que é demonizada.

Em 2017 Lucas Obalera de Deus e Ronilso Pacheco escreveram um artigo intitulado Tráfico, igrejas evangélicas e intolerância religiosa. Nesse artigo os autores, um candomblecista e outro evangélico, afirmam que a relação entre neopentecostalismo e traficantes ou integrantes de facções criminosas não é nova, algo que também é confirmado por Cunha (2014). Nesse contexto,

\begin{abstract}
A figura dos traficantes evangélicos apresentam outros desafios na construção de estratégias de combate ao racismo cultural religioso/intolerância religiosa, uma vez que este "novo" agressor está fora da institucionalidade convencional. Se por um lado, muitas igrejas não têm coragem de fazerem o que o traficante que ordena a destruição do terreiro faz, é comum do universo evangélico orações para que os terreiros fechem, para que terreiros sejam substituídos por igrejas (DEUS; PACHECO, 2017).
\end{abstract}

\footnotetext{
${ }^{20}$ Vagner Marques que escreveu Fé e crime e Lucas Medrado que escreveu Cristianismo e criminalidade (DEUS; PACHECO, 2017, p. 2).

${ }^{21}$ Cunha (2014, p. 62) fala em "abrasileiramento do pentecostalismo" com base em Sanchis (1998) e em "jeitinho brasileiro" com base em Lívia Barbosa (1992) para falar da adaptação do pentecostalismo brasileiro que basicamente gerou o neopentecostalismo, a partir da fundação da IURD em 1977.
} 
Logo, os traficantes evangélicos se somam a uma infinidade de atores socais que violam os direitos e a cultura das RMAs. Explicito que os traficantes não engendraram o discurso demonizante, eles apenas levam esse discurso ao extremo e o praticam da forma mais violenta possível. Essa demonização então passa do plano simbólico do discurso para o plano concreto da realidade e atinge os terreiros.

Deus e Pacheco (2017) defendem que os pastores e lideranças que pregam esse discurso demonizante devem ser responsabilizados por isso, porque essa liberdade religiosa apoiada no racismo religioso estimula agressões das mais variadas ordens contra as RMAs. Entretanto, é preciso apontar que os que calam e ficam em silêncio também consentem e reforçam essa violência.

Um dos interlocutores da pesquisa de campo, o ogã Armando ${ }^{22}$, que é carioca, fez uma descrição do contexto que pode ter ensejado o surgimento dessa categoria. Por mais que ele não cite a categoria terrorismo religioso a fala dele e de outros interlocutores da pesquisa, bem como as matérias jornalísticas consultadas, dão conta desse contexto que ele descreve como sendo um contexto permeado pelo terrorismo religioso. Diz ele:

\begin{abstract}
O que a gente tá assistindo no Rio... como essa população - povos de terreiro - se guarneceu juridicamente para fazer o enfrentamento no campo da democracia, pelo campo do direito? O que que se tá recorrendo agora? À violência sem controle. "Vai bandido, mata aquele macumbeiro lá que a gente absolve vocês, no céu vocês não vão tá preso não". E tem facções aí se considerando, tem facções que tão criando dentro de si, e isso é um perigo grande, inclusive para quem tá promovendo, tão criando dentro de si uma expectativa de poder. Por que veja bem: uma facção que é literalmente armada, de pessoas que não têm nada a perder, que não tinham sentido na vida e que mesmo deformadamente ganham um sentido: representantes de Deus. E que nessa representação justifica inclusive aquilo que é chamado de crime como uma forma de arrecadação em nome de Deus. É isso que eles estão construindo: um verdadeiro exército de homens, mercenários. É parecido, com as devidas diferenças, com as Al Qaeda da vida, Boko Haram da vida, desse movimento islâmico. O que não é islâmico, não é aceito pelo mundo islâmico, mas que toma em armas, tem uma justificativa divina e que aterroriza o mundo todo achando que pode fazer o que quiser porque tá a serviço de Deus. Mas o que ele quer, não o que Deus quer, mas dizendo que é serviço de Deus (Diálogo realizado em: 16/07/2019).
\end{abstract}

Na fala do ogã Armando há, como em matérias de vários sites, a associação do termo terrorismo com o fundamentalismo islâmico ${ }^{23}$. No caso das RMAs defendo que o racismo religioso seja a base desse terrorismo religioso. No primeiro cabem basicamente ataques simbólicos e físicos

${ }^{22} \mathrm{O}$ ogã Armando é ogã do Ilê Omo Tifé e trabalha/trabalhou na Prefeitura de Fortaleza atuando na temática da igualdade racial e afins, além de ser mestre capoeirista.

${ }^{23}$ Aqui é preciso fazer uma crítica pontual a esse senso comum preconceituoso, assaz alimentado pela mídia, acerca de uma relação obrigatória entre Islã e terrorismo. É preciso dizer que esse preconceito violenta muçulmanos no mundo todo que são automaticamente imaginados como terroristas quando dizem que são do Islã ou são identificados com essa religião. 
de menor periculosidade. No segundo, cabem ataques que ameaçam a integridade física do povo de santo, com coerção aos adeptos para quebrarem seus objetos sagrados e a depredação do patrimônio privado e sagrado dos terreiros. Ou seja, o terrorismo religioso é a exacerbação, a radicalização, o clímax do racismo religioso. Assim, ambos se alimentam numa relação de simbiose.

Aqui eu trago um contraponto. Umas das coisas que me surpreenderam durante as entrevistas realizadas na pesquisa de campo foi perceber que nem só de ofensas e ataques vivem os candomblecistas, pois há algumas surpresas agradáveis no cotidiano deles. Logo, o que vai ser narrado foge um pouco do quadro geral de racismo religioso e de violência que foi desenhado até agora. Serão narradas algumas situações nas quais os interlocutores achavam que iam encontrar preconceitos, mas foram surpreendidos com a ausência desses.

Um desses casos é o a da professora Juliana de Oxum ${ }^{24}$ que conta uma experiência que teve com uma ex-aluna. Segue a fala dela:

\begin{abstract}
Eu tenho uma ex-aluna que foi criada a vida inteira dentro da igreja evangélica e hoje não é mais aluna da escola, mas continua fazendo serviço de monitoria, continua indo pra escola sendo voluntária. E ela chegou um dia e me perguntou: "Juliana, mas me diz uma coisa. Qual é mesmo a tua religião?". Eu disse: "Você quer saber mesmo?" "Quero". "Então, vou the contar". Eu contei pra ela e ela disse assim: "Deixa eu ir conhecer". E hoje não sai daqui de dentro do terreiro (risos). Adora um amalá, adora uma flor do velho. Então, ela vem comigo: "Tia, deixa eu dormir na tua casa e amanhã quando tu for trabalhar eu volto contigo", porque ela mora lá no bairro onde eu trabalho (Diálogo realizado em 23/08/2019).
\end{abstract}

Nesse momento resolvi perguntar se essa ex-aluna ainda está na igreja e ela respondeu:

Não, não frequenta mais a igreja. Ela diz assim: "Gente, não é nada do que eles diziam. Não é nada do que o pastor dizia. O pastor dizia que isso, isso e aquilo, mas não é nada do que ele tá dizendo". Eu pergunto a ela: "Ele conhece para falar? Ele tem propriedade pra dizer?" Ela: "Não sei, acho que não, porque não é nada do que ele dizia" (Diálogo realizado em 23/08/2019).

Aqui a figura do pastor aparece como uma daquelas que propaga inverdades e preconceitos contra as RMAs, mas é bom saber que a curiosidade e a experiência num terreiro são suficientes, de alguma forma, para expulsar esses preconceitos da cabeça de uma jovem estudante. Além disso, Juliana, enquanto profissional, sempre se expôs enquanto candomblecista e respondeu com modéstia e coragem às provocações que já ouviu no seu âmbito de trabalho. Ela preza sempre pelo diálogo e ensina, a seu modo, os colegas de trabalho e os alunos a respeitarem a sua religião.

\footnotetext{
${ }^{24}$ Juliana é iaô e filha de Oxum. É professora na educação básica no município do Eusébio (CE).

Oxum é a orixá associada às águas doces e sua cor é o amarelo e o dourado, sinônimos de riqueza e abundância.
} 


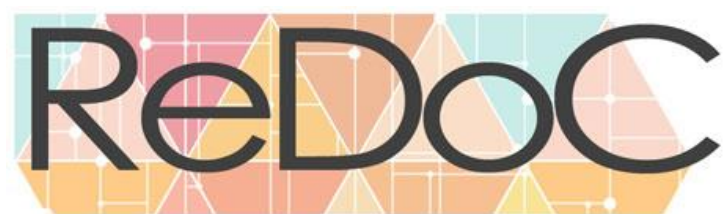

Revista Docência e Cibercultura

Um outro caso nos conta mãe Evelane ${ }^{25}$ que passou por uma situação inusitada. Ela comenta essa experiência que teve no trabalho nos seguintes termos:

Foi igual a mim no ano passado que eu cheguei no meu chefe e disse assim: "Tô com um problema muito grande". Eu ia dar obrigação de quatorze anos. E aí, como eu te disse minha mãe não avisa. Então, ela ligou e disse: "Tal dia você esteja aqui”. E eu: "Putz, acabou as férias". Aí, eu fui lá no meu chefe e eu disse: "Olha [...] eu tô com um problema". Aí, ele: "O que é?". "Eu preciso passar quinze dias em Salvador. Desses quinze dias, sete eu não vou falar com ninguém”. Aí, ele: "Em Salvador? O que que você vai fazer em Salvador?". Aí, eu disse: "Eu vou dar uma obrigação religiosa". Aí, ele: "Sem problema, tire suas férias". "Acontece que eu estou de férias (risos). As férias acabam amanhã e a minha obrigação é daqui a dez dias". Aí, ele olhou assim pra mim e disse: "Obrigação religiosa, né. Fiz uma pesquisa sobre a sua religião. Foi sobre Xangô. Vamo fazer assim: Vá, dê sua obrigação e quando chegar você vai pagando aos poucos. Quando precisar eu lhe coloco num sábado ou num dia à noite". Então, tem o preconceito, tem, mas tem os que ajudam também (Diálogo realizado em 13/08/2019).

Nesse caso, o fato do chefe de mãe Evelane ter feito uma pesquisa sobre Xangô possibilitou que o mesmo entendesse a situação e revolvesse o problema dela, pois sabemos que nem sempre o ambiente profissional é favorável aos adeptos. Os locais de trabalho, depois das escolas e ambientes familiares, sempre aparecem como locais onde o racismo religioso se manifesta de forma frequente.

Uma outra professora, a ekedi Cristiane ${ }^{26}$, também tem uma experiência para contar a partir da sua atuação profissional:

Eu acho que essa questão do Candomblé, muitas vezes, eu sofro indiretamente quando sou apresentada como a professora candomblecista. [...] E aí eu não tô no terreiro, eu tô fora do terreiro. Eu tô na academia e essa academia quer desqualificar esse saber do terreiro porque não entende ele como espaço de saber. [...] Meus alunos sabem, inclusive, eu tenho alunos candomblecistas também. Então, não tenho problema em relação a isso. [...] Inclusive, tem dois TCCs (Trabalho de Conclusão de Curso) de Ciências Biológicas que eu vou orientar agora que tem o viés das RMAs e a relação com as ervas medicinais e a outra é falando sobre as comidas de orixá, comida de santo. [...] A gente tá tentando adentrar nessa produção acadêmica entendendo o terreiro como espaço de produção do saber [...] Teve essas duas surpresas, muito boas. [...] Tem alunas minhas que são católicas e fazem a intervenção na escola com a temática das RMAs, então, em relação a isso é bem tranquilo (Diálogo realizado em 27/11/2019).

Assim, o relato dela aponta a possibilidade do espaço escolar ser também um espaço no qual o respeito às RMAs acontece, por mais incomum que isso seja. Com esses relatos quero apontar

\footnotetext{
${ }^{25}$ Evelane é uma ialorixá que atua na temática da segurança alimentar e nutricional a partir do CONSEA/CE.

${ }^{26}$ Cristiane é ekedi, filha de Ogum e professora de um IFCE. Acrescento duas informações aqui: 1) Ogum é o orixá guerreiro associado ao ferro e ao fogo. 2) Ekedi - cargo feminino: não entra em transe, responsável pelos cuidados quando os orixás estão incorporados nos rodantes e pelo funcionamento direto dos ritos.
} 
a dinâmica do cotidiano, pois não podemos pensar a realidade dos interlocutores apenas do ponto de vista das violências que sofrem, ou seja, é preciso ver além dessa violência e enxergar os pontos de ruptura do racismo religioso que os afeta. A realidade é complexa e cheia de nuances e isso deve ser ressaltado. Porém, esses casos não podem, obviamente, ser usados como forma de relativizar o racismo religioso presente no cotidiano dos adeptos, pois nesse caso, a exceção confirma a regra.

\section{IDENTIDADES REINVENTADAS E DEMANDAS ATUALIZADAS}

Aqui discuto algumas questões que giram em torno de identidades afrorreligiosas que são reinventadas, de tensões que permeiam o cotidiano dos interlocutores e suas percepções sobre o racismo religioso. Essa discussão sobre identidade se relaciona diretamente com a temática do racismo religioso e aponta uma especificidade dentro do contexto das RMAs.

Na pesquisa de campo tive a oportunidade de me aproximar do Coletivo IBILÉ ${ }^{27}$. O Coletivo IBILÉ, que faz diversas articulações políticas e sociais em prol da garantia dos direitos dos povos de terreiro cearenses, conseguiu se reunir em 2018 com o governador do Ceará, Camilo Santana e nessa reunião foram apresentadas demandas do Coletivo em nome dos povos de terreiro. No documento elaborado para essa reunião algumas das demandas se referem especificamente ao racismo e intolerância religiosa, como aponta o tópico 7, intitulado Justiça, Cidadania e Articulação Institucional onde há referências explícitas à essa questão. Seguem alguns itens desse tópico:

7. 1 Combate e repressão à intolerância e ao racismo religioso com transparência, prazos céleres e efetividade, através de uma comissão paritária em que os PCTMA (Povos de Terreiro), SEJUS, Defensoria do Estado e ONGs possam construir estratégias céleres e efetivas;

7. 3 Criação de delegacia ou setor responsável, no âmbito da Secretaria de Justiça e Cidadania (SEJUS), para receber, encaminhar e solucionar crimes de racismo, injúria racial, intolerância religiosa, bem como o devido acompanhamento das vítimas nos programas de acolhimento;

7. 4 Criação do Observatório Permanente das Estatísticas de Racismo e Intolerância Religiosa, com fomento e suporte dentro da CEPPIR, para identificar casos e dar seguimento jurídico e assistência contínua aos cidadãos vitimados" (Proposição político-social de etnodesenvolvimento para os povos e comunidades tradicionais de matriz africana (PCTMA) do Ceará. Fortaleza, 09/07/2018).

${ }^{27}$ O Coletivo Cultural de Matriz Africana IBILÉ é um coletivo que agrega povos de terreiro cearenses para discussões e ações de articulação social e política com fins de promoção de ações afirmativas que reafirmem e garantam os direitos específicos desses povos. Foi criado em dezembro de 2015. 
Esses três itens apontam para a centralidade que a questão do racismo religioso possui entre os povos de terreiro cearenses, pois as notícias de ataques que circulam nas redes sociais são frequentes e permeiam o cotidiano desses povos ${ }^{28}$. No referido documento ${ }^{29}$ há referências tanto ao racismo religioso quanto à intolerância religiosa, de forma que ambos se alternam e se complementam, sendo que na legislação que combate a discriminação religiosa o termo intolerância é o que está em voga. Além disso, foi possível constatar que por mais que o conceito de racismo religioso esteja majoritariamente presente nas falas dos candomblecistas, há adeptos ligados à Umbanda e à Jurema que também falam em racismo religioso.

É importante apontar que os adeptos das RMAs possuem visões distintas sobre si mesmos nos vários Estados do país, pois é possível que a compreensão de si mude a partir de realidades geográficas distintas ${ }^{30}$. Por exemplo: no Ceará, algumas lideranças candomblecistas do Coletivo IBILÉ praticam um movimento político-social de se afirmarem enquanto povos culturalmente diferenciados, ou seja, afirmam muito mais o aspecto cultural de suas identidades religiosas em vez de se afirmarem apenas como religião, principalmente, no diálogo necessário que eles têm que estabelecer com o Estado. Essa auto-afirmação cultural acabou se tornando então uma tendência nacional entre os adeptos de Candomblé ${ }^{31}$, como apontam Capponi e Araújo (2015). Esse movimento dos candomblecistas tem as suas razões de ser. A principal delas é a possibilidade de acessarem políticas públicas enquanto povos e comunidades tradicionais de matriz africana, que é a nomenclatura oficial prevista na legislação para os povos etnicamente distintos de outros grupos socais que habitam o território brasileiro.

Essa reinvenção da identidade candomblecista não veio de forma gratuita, mas aponta para a intelectualização e politização da população afrorreligiosa. A partir de uma aproximação entre terreiro, academia e movimentos sociais fomentou-se um trânsito constante de indivíduos entre essas três esferas sociais. O decreto 6.040/2007 prevê uma proteção legal aos PCTs que mesmo sendo desrespeitada serve de base para afirmação dos povos de terreiro enquanto povos e não

\footnotetext{
${ }^{28}$ Mais à frente serão discutidos os motivos das RMAs estarem se identificando, atualmente, enquanto povos de terreiro ou povos e comunidades tradicionais de matriz africana (PCTMA).

${ }^{29}$ Proposição político-social de etnodesenvolvimento para os povos e comunidades tradicionais de matriz africana (PCTMA) do Ceará, 2018.

${ }^{30}$ Em Recife, por exemplo, o movimento afrorreligioso é diferente. Em 2018, apresentei um trabalho prévio de pesquisa em um evento na Universidade Federal de Pernambuco (UFPE) acerca das mobilizações do Coletivo IBILÉ. Na ocasião um candomblecista me questionou sobre essa ênfase cultural dos povos de terreiro cearenses, pois os adeptos pernambucanos estavam fazendo o movimento de se afirmarem apenas como religião e não como povos tradicionais como os cearenses estavam fazendo.

${ }^{31}$ Durante a pesquisa de campo ficou implícito o fato de que umbandistas e juremeiros fora desse Coletivo não se afirmam, via de regra, como povos culturalmente diferenciados. Já os que fazem parte desse Coletivo costumam se afirmar assim, o que indica um certo consenso entre as RMAs que fazem parte desse Coletivo.
} 


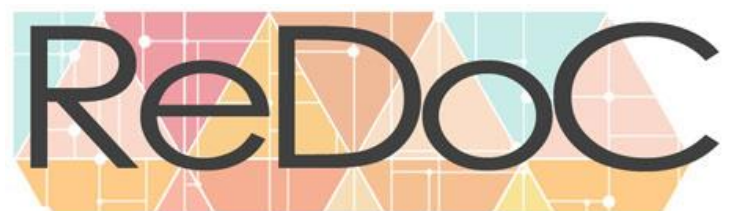

Revista Docência e Cibercultura

apenas como religião. Na negociação que os terreiros fazem com o Estado é preciso criar uma linguagem que abranja a violência pela qual eles passam, indo além da religião.

No artigo "Eu me declaro": diálogo sobre transformações, auto-definições e reivindicações políticas nos cultos afro-brasileiros (2015) o professor Patrício Araújo e a antropóloga Giovanna Caponni discutem esse fenômeno de redefinição da identidade candomblecista. Os autores discutem a importância do Movimento Negro junto aos terreiros para demandar direitos e enfatizam a redefinição da nomenclatura usada pelo povo de santo para se auto-definir. De forma geral, os casos de racismo religioso, o decreto 6.040 e as ações judiciais envolvendo as RMAs e a IURD constituíram o contexto social que estimulou os adeptos a repensarem a própria identidade e a se afirmarem como povos tradicionais de matriz africana ou povos tradicionais de terreiro (CAPONNI; ARAÚJO, 2015).

Pode parecer pouca coisa, mas isso influencia na forma como cada uma das RMAs enxerga os ataques contra elas. Para os que se afirmam apenas como religião - como umbandistas e juremeiros cearenses têm feito, em geral - os ataques contra eles são definidos por eles mesmos como intolerância religiosa. Pode-se então indagar: por que a reivindicação do uso da expressão racismo religioso está mais presente no Candomblé? Essa reivindicação se deu a partir da intersecção entre movimentos negros e terreiros, fato este comprovado por vários interlocutores da pesquisa que em determinados momentos declararam ligação direta ou indireta com movimentos negros ou com a luta antirracista, algo que já foi discutido e confirmado por Nailah Veleci (2017, p. 89).

Assim, para os que se afirmam como povos ou comunidades tradicionais os ataques são definidos por eles mesmos como racismo religioso, pois têm uma compreensão de si que vai além da religiosidade. Nesse caso, o racismo religioso tem um sentido de uma discriminação contra um povo etnicamente distinto de outros que habitam o território brasileiro, como já foi apontado. Esse é um racismo que discrimina a religião de determinados povos e ao mesmo tempo discrimina esses povos que ela representa.

A diversidade ancestral do Candomblé representada a partir das nações que o compõem como Ketu, Angola, Jeje-nagôo ${ }^{32}$ e etc, endossa mais ainda esse aspecto cultural que tem raízes nos territórios africanos. O terreiro de Candomblé opera numa lógica de perpetuação de uma tradição afro-diaspórica que se reproduz nele. Ao se afirmarem como cultura e não apenas como

\footnotetext{
${ }^{32}$ Ketu é nome que se dá à nação composta por ancestrais iorubás; Angola é o nome que se dá à nação composta por ancestrais bantos; jeje é o nome da nação composta por ancestrais daomeanos (atuais Benin e Togo, por exemplo). Logo, essa lógica étnico-geográfica africana foi transportada para os Candomblés brasileiros. Apesar dessas distinções feitas é preciso enfatizar que há cruzamentos dessas matrizes étnicas. Essas divisões indicam muito mais referências culturais básicas do que propriamente fronteiras absolutas, pois existem terreiros que tocam para mais de uma nação - jeje-nagô ou jeje-bantu, por exemplo.
} 
religião os candomblecistas cearenses estão resignificando a si mesmos e a sua visão de mundo, pois nesse caso, a religião seria um aspecto específico de um complexo civilizacional de matriz africana. Nesse sentido, a religião enquanto componente da cultura ordena e reforça o ethos - o caráter e a qualidade de vida, o estilo e disposições morais e estéticas de um povo (GEERTZ, 2008) - do grupo que a concebeu.

Para reforçar essa ideia cito Karen Armstrong (2009) que ao tratar da experiência traumática dos judeus sob a tirania de Isabel e Fernando da Espanha descreve como a repressão ao judaísmo afetou a prática religiosa dos judeus na Espanha. Em sua argumentação Armstrong (2009) defende que o rito é a concretização do mito ${ }^{33}$ e que a prática do rito alimenta o mito. Porém, a partir do momento em que essa prática ritual passa a ser perseguida e deixada de lado o mito perde força e sentido e isso altera o próprio ethos do grupo que começa a ter a sua identidade étnica alterada (ARMSTRONG, 2009, pp. 34-38). Nesse caso, esse exemplo serve para reforçar a vinculação íntima que existe entre religião e identidade étnica, explicitando assim que a identidade de um grupo étnico pode ser fortemente abalada a partir de um ataque direto à sua religião. Essa relação entre religião e identidade étnica foi discutida também por Rosenilton Oliveira (2017) a partir do catolicismo, do Candomblé e do meio evangélico, o que indica a importância de pensar essa relação que se estabelece de diversas maneiras e em diversos contextos.

No caso candomblecista essa percepção enquanto povo é explicada pelo ogã Leno:

Nós somos povo porque nós temos vários idiomas, uma cultura díspar da cultura eurocêntrica que está instalada, uma cultura pautada na ancestralidade africana através da oralidade, da preservação de gestos, de atos, de funções, de liturgia, de convívio social, de dança, de música, de alimento, de etnodesenvolvimento no artesanato, na construção de instrumentos musicais, na construção de móveis, de agricultura, de extrativismo... (Diálogo realizado em 11/07/2019).

Vinculando essa especificidade cultural ao racismo religioso ele também fala como os iurdianos construíram a narrativa demonizante sobre as RMAs, em quem colocam a culpa de diversos males, com intuito comercial e financeiro, nos termos dele. Ao se referir ao discurso demonizante de sua religiosidade ele diz:

[...] É dizer que quando eu botar o pé no chão eu não posso saudar meus ancestrais, que eu só posso falar com Deus, Javé, com o Deus de Abraão. Isso sim é muito complexo. Não é só questão religiosa, é questão cultural. [...] Que a minha alimentação é satânica. Eu como omolocum, acarajé, abará, aberém, eu não posso comer nada mais disso que é coisa do diabo? E aí? Onde fica a minha vida todinha? Eu vou cair numa crise existencial (Diálogo realizado em 11/07/2019).

\footnotetext{
${ }^{33}$ Em Armstrong (2009) o mito é uma narrativa que dá significado ao mundo no qual se vive. Nesse caso, o mito é uma narrativa que ordena simbolicamente o mundo judeu em diáspora ao dar significados que expliquem a realidade.
} 
Logo, fica explícito o quanto o racismo religioso ao atacar a religiosidade negra ataca também todo o complexo cultural afro que se manifesta nos terreiros, pois essa cultura é o que dá sentido de vida aos candomblecistas. Além disso, o ogã Leno aponta que a partir do governo Lula começou-se uma nova discussão em torno dos PCTs no Brasil:

Esse povo é reconhecido como, o que o povo chamava de religião, de terreiro de macumba, e vira povos e comunidades tradicionais de matrizes africanas. Como povo o território é sagrado, deixa de ser apenas um território religioso para ser território cultural, uma embaixada do país de origem [...] (Diálogo realizado em 11/07/2019).

Pai Linconly ${ }^{34}$ também comenta sobre essa questão identitária do povo de santo, aliando-a ao racismo religioso e enfatizando a contribuição importante desse conceito ele diz:

A questão do racismo religioso pode nos ajudar a ampliar a compreensão. Por que eu posso ser intolerante com você. Quando eu venho a tratar da categoria racismo religioso eu consigo entender uma gama de outros elementos para esse fenômeno. Como, por exemplo, a perseguição policial, quando um filho de santo branco ou negro vai para a escola com cabelo raspado e lá isso ter uma significação de perseguição dos colegas e dos professores, como a ascensão dos candomblecistas à universidade... então eu vejo que essa categoria racismo religioso ela me ajuda a ter um leque maior para abarcar um entendimento de muita coisa. Por que quando eu vou falar de Candomblé, de povos de terreiro, eu não vou falar de uma só matriz, eu vou falar da compreensão de povo e de mundo. E esse mundo e esse povo é que vai sofrer esse racismo com base no modo de vida de uma ilha de África que é o terreiro. Eu acho que dá pra você ver mais elementos a partir dessa categoria (Diálogo realizado em 15/08/2019).

Assim, com o conceito de racismo religioso é possível ampliar o leque de possibilidades de compreensão do fenômeno da discriminação contra as RMAs. O aprofundamento dessa compreensão se pauta exatamente na identidade étnico-cultural dessas religiosidades que abarcam um modo de vida distinto. Baba Cleudo ${ }^{35}$ também dá a sua contribuição nessa questão ao dizer o seguinte acerca da prática religiosa candomblecista:

Cultuar a natureza, proposta de preservação da mesma e da tradição cultural dos povos africanos, que se manifesta na religião - função do candomblé. Culto ao corpo, ao alimento, ao prazer; guardar a riqueza da memória, dos povos, dos cânticos, a alegria, o diálogo - riqueza africana; função política do sacerdote, como se relaciona com os outros, com os diferentes grupos, indígenas, ciganos, judeus, quilombolas, mascates, vaqueiros; são valores da comunidade [...] (Diálogo realizado em 08/05/2019).

\footnotetext{
${ }^{34}$ Pai Linconly é babalorixá e professor do curso de Pedagogia na UNILAB - CE.

${ }^{35}$ Baba Cleudo é um babalorixá bem conhecido no cenário cearense por sua militância social e por ser um dos mais velhos pais de santo do Estado. Enfatizo aqui que os "mais velhos" no Candomblé gozam de respeito e prestígio por sua experiência e conhecimento religiosos.
} 


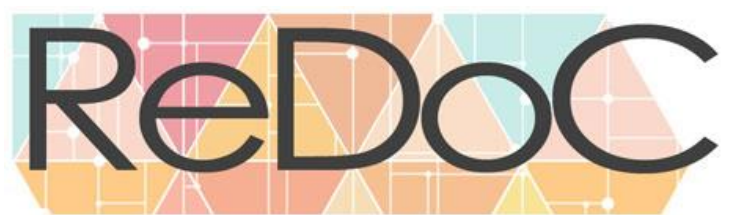

Revista Docência e Cibercultura

Em resumo, na visão de Baba Cleudo, o candomblé é uma tradição cultural expressa numa religião que cultua a natureza e o ser humano, sendo que essa religião carrega em si uma riqueza de manifestações culturais que lhes são próprias.

\section{CONCLUSÃO}

Refletindo sobre a minha experiência acadêmica aliada à minha experiência religiosa pessoal, percebi que, ao reler os diários de campo, alguns fatos que ocorreram na igreja que eu frequentava se relacionam diretamente com o racismo religioso, que ainda é muito presente no meio evangélico, infelizmente. Antes de perceber isso, o conceito de racismo religioso me parecia apenas uma abstração teórica, mas depois senti a materialidade dessa lógica racista ao ver qualquer elemento africano sendo associado a coisas ruins e demoníacas. Ressalto isso, porque é importante apontar o discurso que legitima as violências contra as RMAs. De uma forma geral, a intolerância, o racismo e o terrorismo religiosos se vinculam aos discursos de púlpitos evangélicos que demonizam essas religiosidades.

$\mathrm{O}$ que os levantamentos e mapeamentos apontam no sentido das violações de direitos com cunho religioso se relaciona diretamente com o ódio histórico ao negro e a tudo o que ele produz no campo da cultura e que se manifesta na religiosidade. Na tentativa de compreender esse ódio ao negro que gerou categorias como guerra santa, intolerância, racismo e terrorismo religioso devemos nos perguntar quando essa violência irá acabar. É possível que acabe? Apesar de todos os avanços, leis e iniciativas, porque o país ainda não deu cabo do seu racismo e terrorismo religiosos? Por que se permitem atentados aos terreiros?

Para finalizar de modo otimista e apesar de falar em casos de intolerância, racismo religioso e terrorismo, afirmo que é possível construir a longo prazo uma cidadania espiritual em moldes democráticos, como propõe Moraes (2016, p. 24). Percebo que o respeito à identidade afrorreligiosa é algo ainda em construção. Devemos nos perguntar por que não se tolera, no sentido do respeito, o vizinho que vai pra macumba e paga seus impostos, trabalha, estuda e ama como qualquer outra pessoa? Por que a empatia e a compreensão com os afrorreligiosos ao invés de ser exceção não pode ser a regra? Pensemos.

\section{REFERÊNCIAS}

AMORIM, Diego. Líderes religiosos de Campos relatam ataques e ameaças de traficantes a terreiros. 10 set. 2019. Disponível em: < https://extra.globo.com/casos-de-policia/lideres-

\begin{tabular}{l|l|l|l|l|l|l|} 
(C) Redoc & Rio de Janeiro & v. 5 & n.2 & p. 70 & Maio/Ago 2021 & ISSN 2594-9004
\end{tabular}




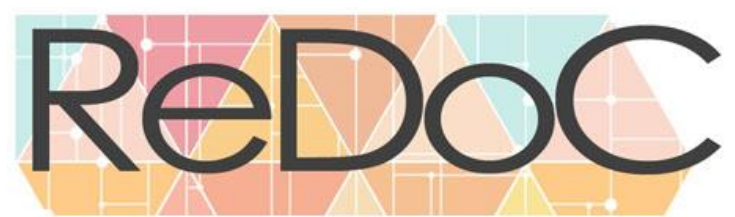

Revista Docência e Cibercultura

religiosos-de-campos-relatam-ataques-ameacas-de-traficantes-terreiros23938758.html?versao=amp\&_twitter_impression=true >. Acesso: 30 nov. 2020.

ARMSTRONG, Karen. Em nome de Deus: o fundamentalismo no judaísmo, no cristianismo e no islamismo. Tradução de Hildegard Feist. São Paulo: Companhia das Letras, 2009.

BALLOUSSIER, Anna Virginia. Polícia prende 8 traficantes do 'Bonde de Jesus', que atacava terreiros no Rio. Disponível em: <

https://www1.folha.uol.com.br/cotidiano/2019/08/policia-prende-8-traficantes-do-bonde-dejesus-que-atacava-terreiros-no-rio.shtml >. Acesso: 13 set. 2020.

BUSTAMANTE, Luisa. "Em nome de Jesus", bandidos destroem terreiro no Rio. 8 out. 2017. Disponível em: < https://veja.abril.com.br/brasil/em-nome-de-jesus-bandidos-destroemterreiro-no-rio/ >. Acesso: 13 set. 2020.

CAPETTI, Pedro; CANÔNICO, Marco Aurélio. Denúncias de ataques a religiões de matriz africana sobem 47\% no país. 26 jan. 2019. Disponível em: <

https://oglobo.globo.com/sociedade/denuncias-de-ataques-religioes-de-matriz-africanasobem-47-no-pais-23400711 >. Acesso: 13 set. 2020.

CAPONNI, Giovanna; ARAÚJO, Patrício Carneiro. “Eu me declaro”: diálogo sobre transformações, auto-definições e reivindicações políticas nos cultos afro-brasileiros. 2015.

CUNHA, Christina Vital da. Religião e criminalidade: traficantes e evangélicos entre os anos 1980 e 2000 nas favelas cariocas. Religião e Sociedade, Rio de Janeiro, 34 (1): 61-93, 2014.

DEUS, Lucas Obalera de; PACHECO, Ronilso. Tráfico, igrejas evangélicas e intolerância religiosa. Blog Negro Belchior. 2017. Disponível em: < https://negrobelchior.com.br/traficoigrejas-evangelicas-e-intolerancia-religiosa/ > . Acesso: 30 nov. 2020.

FONSECA, Alexandre Brasil; ADAD, Clara Jane (orgs.). Relatório sobre intolerância e violência religiosa no Brasil (2011-2015): resultados preliminares. Brasília, Secretaria Especial de Direitos Humanos, 2016.

GEERTZ, Clifford. A interpretação das culturas. 1. ed., 13. Reimpr. Rio de Janeiro: LTC, 2008.

GONÇALVES, Juliana. 20 set. 2017. Ataques a religiões de matriz africana fazem parte da nova dinâmica do tráfico no Rio. Disponível em: <

https://theintercept.com/2017/09/20/ataques-a-religioes-de-matriz-africana-fazem-parte-danova-dinamica-do-trafico-no-rio/ > . Acesso: 13 set. 2020.

GUALBERTO, Marcio Alexandre M. Mapa da Intolerância Religiosa - Violação ao Direito de Culto no Brasil. Associação Afro-brasileira Movimento de Amor ao Próximo (Aamap). Rio de Janeiro, 2011.

LEWER, Laura. 9 out. 2020. 'Passei a conhecer muito de mim depois que comecei a cantar', diz Fabiana Cozza. Disponível em: < https://www.acidadeon.com/NOT,0,0,1550927,Passei-a- 


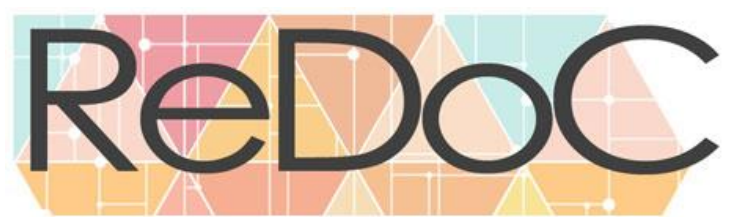

Revista Docência e Cibercultura

conhecer-muito-de-mim-depois-que-comecei-a-cantar-diz-Fabiana-Cozza.aspx >. Acesso: 21 abr. 2021.

MAXX, Matias; FALEIROS, Deborah. Nação de Jesus - fuzis ungidos e grafite gospel em muros da comunidade: para fação do Rio, a lei do tráfico é a lei de Deus. 27 mai. 2020. Disponível em: < https://tab.uol.com.br/edicao/nacao-de-jesus/\#page10 >. Acesso: 13 set. 2020.

MORAES, Roberto José Nery. Teoria geral do racismo religioso: crime de ódio. Revista Tempo Amazônico, p. 15-28, v. 4, n. 1, jul/dez de 2016.

MOZENA, Danielle. Resenha: GUALBERTO, Marcio Alexandre M.: Mapa da Intolerância Religiosa 2011: violação ao direito de culto no Brasil. Rever - Revista de Estudos da Religião, ano 11, n², Jul/Dez, 2011.

OLIVEIRA, Flávia. Ataques a terreiros é terrorismo. 19 jul. 2019. Disponível em: < https://oglobo.globo.com/opiniao/ataque-terreiros-terrorismo-23818118 >. Acesso: 30 nov. 2020.

OLIVEIRA, Rosenilton Silva de. A cor da fé: "identidade negra" e religião. 262 p. Tese de Doutorado em Antropologia Social, Universidade de São Paulo, São Paulo, 2017.

OUCHANA, Giselle. Mais de 200 terreiros estão ameaçados no estado, diz pai de santo. 09 set. 2019. Disponível em: < https://oglobo.globo.com/rio/mais-de-200-terreiros-estaoameacados-no-estado-diz-pai-de-santo-23937214 >. Acesso: 13 set. 2020.

SOARES, Rafael. Traficantes proíbem candomblé e até roupa branca em favelas. 10 set. 2013. Disponível em: < https://oglobo.globo.com/rio/traficantes-proibem-candomble-ateroupa-branca-em-favelas-9892892 >. Acesso: 13 set. 2020.

VELECI, Nailah Neves. Cadê Oxum no espelho Constitucional? Os obstáculos sóciopolíticos-culturais para o combate às violações dos direitos dos povos e comunidades tradicionais de terreiro. 145 p. Dissertação de Mestrado em Direitos Humanos e Cidadania, Universidade de Brasília, Brasília, 2017.

Este é um artigo de acesso aberto distribuído sob os termos da Licença Creative Commons Atribuição Não Comercial-Compartilha Igual (CC BY-NC- 4.0), que permite uso, distribuição e reprodução para fins não comerciais, com a citação dos autores e da fonte original e sob a mesma licença. 